\title{
Validation of the Arabic version of the Childhood Illness Attitudes Scales
}

Walid AlQerem¹, Jonathan Ling ${ }^{2}$ and Wassan Jarrar ${ }^{1}$

${ }^{1}$ Faculty of Pharmacy, Al-Zaytoonah Private University of Jordan, Amman, Jordan. ${ }^{2}$ School of Nursing and Health Sciences, University of Sunderland, Sunderland, United Kingdom (Correspondence to: W. AlQerem: waleed.qirim@zuj.edu.jo).

\begin{abstract}
Background: Excessive health anxiety can lead to significant disorders such as hypochondriasis. In children, assessment of the severity of health anxiety has been performed using the Childhood Illness Attitudes Scales (CIAS); however, no validated Arabic version of this tool exists.
\end{abstract}

Aims: This study developed and validated an Arabic version of the CIAS questionnaire in Jordan in 2017 to provide a tool to measure the severity of health anxiety in the Arabic-speaking world.

Methods: The CIAS was translated from English to Arabic then back-translated by a different translator and the 2 versions were compared before cognitive interviews were conducted. The final version of the questionnaire was circulated to 597 children. Of these, 200 were asked to retake the questionnaire after 10-15 days to evaluate test-retest reliability. Confirmatory factor analysis (CFA) on the 4-factor model suggested by the original questionnaire version was performed. Internal consistency and test-retest reliability were evaluated.

Results: The CFA showed good fit (goodness of fit index $=0.92$ ) with the 4 -factor model of fears, help seeking, treatment experience, and symptom effects. Test-retest reliability was high and the model had good discriminant validity and internal consistency.

Conclusions: The Arabic version of the CIAS provides a suitable tool to investigate the prevalence and severity of childhood anxiety in the Middle East.

Keywords: Arabic, Childhood Illness Attitudes Scales, confirmatory factor analysis, health anxiety, Jordan

Citation: AlQerem W; Ling J; Jarrar W. Validation of the Arabic Version of the Childhood Illness Attitudes Scales. East Mediterr Health J.

2020;26(6):668-679. https://doi.org/10.26719/emhj.20.068

Received: 24/04/18; accepted: 30/01/19

Copyright (c) World Health Organization (WHO) 2020. Open Access. Some rights reserved. This work is available under the CC BY-NC-SA 3.0 IGO

license (https://creativecommons.org/licenses/by-nc-sa/3.o/igo).

\section{Introduction}

Health anxiety is an experience that we undergo when we misinterpret benign bodily sensations as being indicative of having a serious disease (1). The severity of this experience differs among individuals (2). Mild, occasional health anxiety is normal as it motivates one to seek clinical assistance when experiencing ambiguous bodily changes; such sensations usually soon fade away when medical staff give reassurance that there is no serious disease (1). Being convinced of having a serious disease despite medical reassurance of having good health is a feature of excessive health anxiety. Severe health anxiety can lead to clinically significant disorders such as hypochondriasis, disease phobia (3-5) and panic attacks (5). Sometimes, severe health anxiety can interfere with daily activities such as schoolwork (6) or social activities (7). Health anxiety can also lead to overutilization of healthcare services and therefore increase healthcare costs (8). Somatization accounts for $15-20 \%$ of yearly healthcare expenditure in the United States of America (9). This includes the cost of emergency room visits, hospitalization, unnecessary diagnostic expenses, and invasive procedures (10).

The prevalence of excessive health anxiety has been assessed in several studies. Most of these studies concentrated on assessing the severity of health anxiety in adults or adolescents (11,12). Few studies have focused on children, and although some work has shown that children might experience fears related to health issues or death $(13,14)$, the prevalence of such health anxiety conditions in children is not well understood $(15,16)$. However, some studies estimated that the prevalence of health anxiety in primary care paediatric settings was $25-50 \%$ of visits (17) and was more common in girls (7).

Although it has been shown that frequencies of illness anxiety disorder are similar across countries and cultures (18), the prevalence of the condition in Jordan has not yet been evaluated, or its burden on the health sector. Thus, adaptation of a validated tool to measure the prevalence and burden of health anxiety is urgently required.

In order to apply treatments that are available for excessive health anxiety, an assessment of the severity and prevalence of such health anxiety conditions should be performed. Such assessment of the severity of health anxiety can be performed using questionnaires such as the Illness Attitudes Scales (IAS) (19). In previous work, assessment of the severity of health anxiety was performed in Canadian children aged 8-15 years, using the Childhood Illness Attitude Scales (CIAS), a simplified 
form of the IAS adapted to suit school-aged children $(15,16)$. The CIAS measures fears, beliefs and attitudes associated with health anxiety and abnormal illness behaviour in childhood.

The aim of this study was to develop an Arabic version of the CIAS and to examine its validity in a large sample of schoolchildren aged 10-16 years in Jordan. The validated questionnaire can then be applied to different parts of the Arabic-speaking world throughout the Middle East and North Africa. This Arabic version of the CIAS will allow researchers and health authorities to examine childhood health anxiety and develop an understanding of potential solutions, in regions where this was hitherto impossible. Furthermore, given comparable psychometric properties, this Arabic version will also allow researchers to make comparisons with data collected using the original English version of the CIAS from other regions.

\section{Methods}

\section{Participants}

The original sample included 310 boys and 347 girls aged 10-16 years from 2 schools in Amman, Jordan. Of these, 60 children participated in cognitive interviews, with the remaining 597 completing the questionnaire. The mean age of the participants was 13.55 (standard deviation 2.02) years. The principals of the 2 schools were approached to obtain their approval. We circulated the parental consent form to the children with the help of teachers who agreed to participate. All children who returned a signed consent form and completed the questionnaire were included in the study. Ethical approval for the research was obtained from Al-Zaytoonah University Research Ethics Committee.

\section{CIAS}

The CIAS (16) is a 35-item self-report questionnaire (Appendix 1) that was formulated based on the IAS questionnaire (19). The CIAS uses simplified words and phrases to be more suitable for children. The appropriateness and clearness of the simplified questions were confirmed in a pilot study that interviewed children and received their feedback (16). The questionnaire was validated by evaluating the correlations between CIAS total scores obtained from 200 children and other self-report measures including Fear Survey Schedule for Children-Revised (20), Childhood Anxiety Sensitivity Index (21) and Children's Depression Inventory (22). The CIAS contains 4 factors that explore fears, help seeking, treatment experience and symptom effects, and these were confirmed by applying exploratory factor analysis (EFA) (15).

Thirty-three items of the questionnaire were rated on a 3 -point Likert scale $(1=$ none of the time, $2=$ sometimes, $3=\mathrm{a}$ lot of the time). Items 29-31 measured the frequency of various treatment experiences $(1=0$ times, $2=1$ or 2 times, $3=\geq 3$ times). Thirty-three of the 35 items were used in scoring while the remaining 2 questions were open ended and provided additional information about the patients' medical history.

\section{Data collection}

The CIAS was translated from English to Arabic then back-translated by a different translator, and the 2 versions were compared. A school was approached in Amman to obtain data. Initially, 60 cognitive interviews were conducted with 60 children aged 9-16 years after obtaining their parents' approval, and confirming that all questions were clear and could be understood by the children. The translated questionnaire is shown in Appendix 2. A parental consent form was circulated to an additional 680 children and 597 parents' approved that their children's participation in the study. Of the 597 children, 200 were asked to retake the questionnaire after 10-15 days.

Several methods for determining the appropriate sample size for conducting a confirmatory factor analysis (CFA) and EFA have been proposed. However, Myers et al. (23) found that data from 500 individuals provide sufficient power for $99.9 \%$ of samples. Therefore, we aimed to collect data from at least 500 participants.

\section{Statistical analysis}

The items were treated as ordinals and the normality of scores on each subscale of each model was assessed by calculating kurtosis values. Normality was assumed when kurtosis was between -2 and +2 (24).

The suitability of the data for factor analysis was evaluated using the Kaiser-Meyer-Olkin value and Bartlett's Test of Sphericity. CFA on the 4-factor model was conducted using AMOS version 22 and SPSS version 20. Item loadings were examined and goodness of fit evaluated by calculating minimum discrepancy (CMIN/ $\mathrm{DF}$ ), goodness of fit index (GFI), Tucker-Lewis index (TLI), comparative fit index (CFI) and root mean square error of approximation (RMSEA). Acceptable values are $<5$ for CMIN/DF, $<0.05$ for RMSEA and > 0.9 for GFI, CFI and TLI (25). A cutoff of 0.3 was used to determine if items loaded on a factor, and the correlations between the factors were evaluated using Pearson's correlation to examine discriminant validity.

EFA was conducted using principal-components analysis to evaluate a suitable model for the data after determining that the 4 -factor model that included 33 items was unsuitable for our data. To determine the appropriate number of factors to extract, parallel analysis (Eigenvalue Monte Carlo Simulation) was conducted using O'Connor's SPSS syntax (26), and scree plots.

A pattern matrix was generated using oblimin rotation, which was chosen because the correlation between factors 1 and 4 exceeded the cutoff point of 0.32 $(\mathrm{r}=0.35)$. Any communality below 0.4 was excluded. The factor correlation matrix was evaluated to determine discriminant validity. Internal consistency for each subscale was evaluated by calculating Cronbach's $\alpha$ and the final model was re-evaluated using CFA with the maximum likelihood method. Finally, test-retest reliability was measured using Pearson's correlation.

The ceiling and floor effects were evaluated by calculating the percentage of participants that had 
the highest or lowest possible scores; the effect was considered present when the subjects that achieved these scores exceeded $15 \%$ (27).

\section{Results}

The Kaiser-Meyer-Olkin test result was 0.9 and Bartlett's Test of Sphericity was significant $\left[\chi^{2}(496)=18\right.$ $145.56, P<0.01]$, which indicated the suitability of the data for factor analysis. When examining the communalities, Item 8 (Do you try not to have habits that may be bad for you?) and Item 15 (When your doctor tells you that you are not sick, do you not believe him/her?) had low communality $(<0.2)$ and were excluded from the analysis. EFA was rerun after excluding Items 8 and 15. Scree plots were examined and suggested 4 factors (Figure 1); as four eigenvalues are present left of the "elbow" of the graph.

The 4-factor model was confirmed when conducting parallel analysis. The 4-factor model included fears, help seeking, treatment experience and symptom effects. The communalities of the items included in the 4-factor model were all > 0.4 (Table 1) and the lowest loading was 0.65 (Item 3 in the Fear subscale: Does the thought of being sick scare you? (Table 2). Cronbach's $\alpha$ values were examined and the lowest was 0.85 for treatment experience. Removing any further items would not improve the reliability. Subscale names, item numbers, factor loadings, communalities, and Cronbach's $\alpha$, means, standard deviations and kurtosis for the 4-factor model are shown in Tables 1 and 2. Cronbach's $\alpha$ indicated good internal consistency. Correlations between the 4 factors were examined using Pearson correlations and all were low, which indicated good discriminant validity. The kurtosis for the 4 subscales was between -2 and 2 , which indicated normality.
CFA of the suggested 4-factor model including the 31 remaining items with 5 -error covariance in the same factors yielded acceptable model fit indicators (CMIN/ $\mathrm{DF}=2.58, \mathrm{GFI}=0.9, \mathrm{CFI}=0.96, \mathrm{TLI}=0.96$ and $\mathrm{RMSEA}$ $=0.049$ ). Test-retest reliability was tested by Pearson's correlations and all the items were highly correlated (all $>0.7$, with most $>0.8$ ).

The ceiling and floor effects were evaluated by calculating the percentage of subjects that had the highest or lowest possible scores, and none of the factors exceeded the $15 \%$ cutoff point (27).

\section{Discussion}

This study formulated and validated an Arabic form of the CIAS Questionnaire (16). The results of the EFA resembled the original 4-factor model suggested by Wright et al. (15). These factors consist of fear of illness, death, disease and pain, and help seeking that evaluated seeking treatment and avoiding unhealthy foods, symptom effects and treatment experience that were present in the original IAS study (19). Symptom effects measure the troublesome effects of symptoms on daily activity. However, there were some differences between the Arabic version of the CIAS and the English version of Wright et al.: Items 11, 15 and 25 had loading issues in their designated factor in the study of Wright et al. and therefore were excluded from the model. We included treatment experience (Items 11 and 15) and symptom effects (Item 25) in our final model. We excluded Item 8 because of low communalities, although Wright et al. found this item loaded on the factor treatment experience, so it was removed in the final model to improve reliability. This was reasonable considering that Item 8 (Do you try not to have habits that may be bad for you?)

\section{Figure 1 Scree plot results indicating 4 eigenvalues left to the "elbow" of the graph}

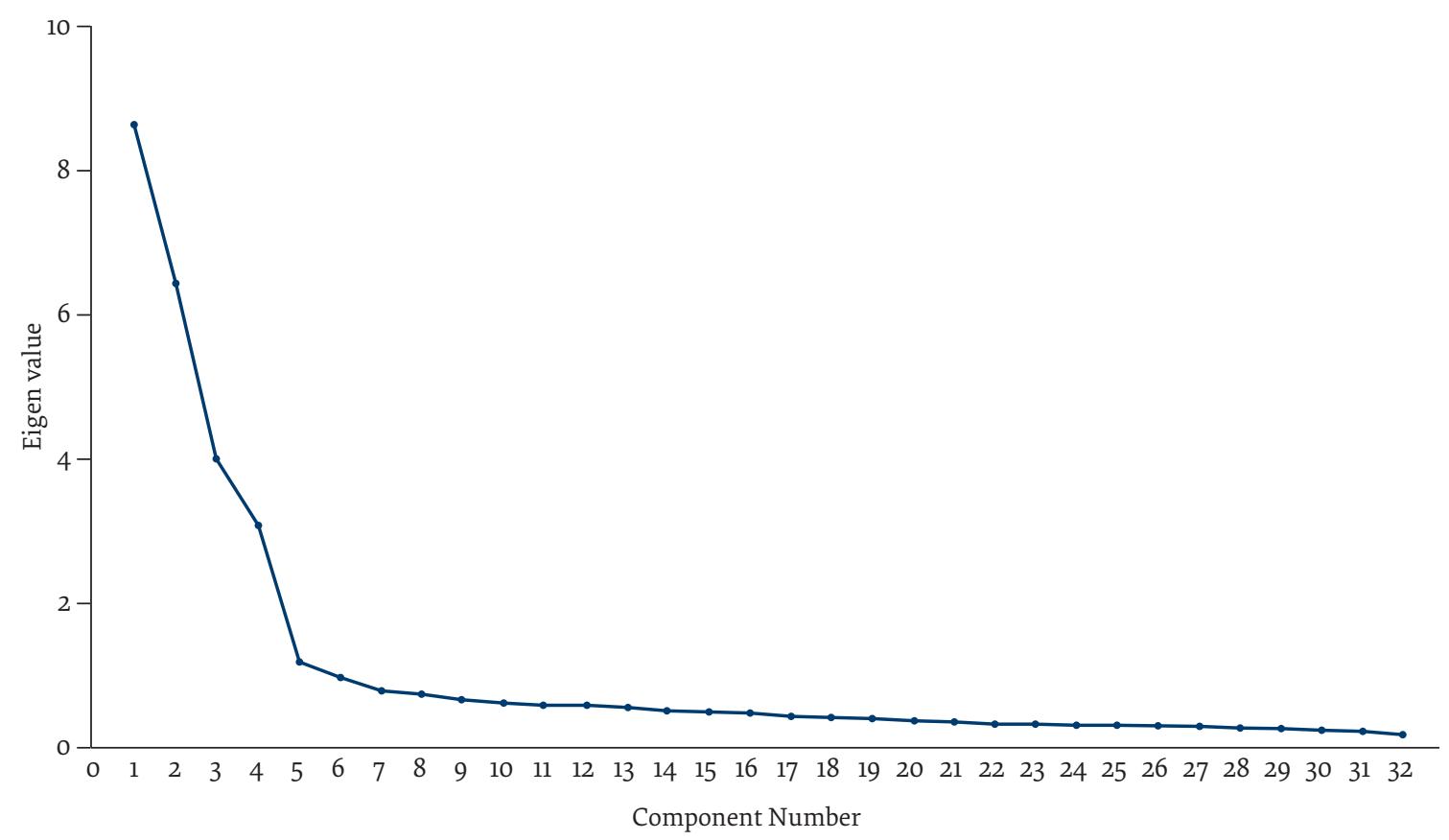




\begin{tabular}{|c|c|c|c|c|}
\hline $\begin{array}{l}\text { Subscale } \\
\text { (Item nos.) }\end{array}$ & $\begin{array}{l}\text { Communalities } \\
\text { min-max }\end{array}$ & $\begin{array}{c}\text { Cronbach's } \\
\alpha\end{array}$ & Mean (SD) & Kurtosis \\
\hline $\begin{array}{l}\text { Fear } \\
(1-4,7,16-23)\end{array}$ & $0.45-0.83$ & 0.96 & $2(0.638)$ & -1.27 \\
\hline $\begin{array}{l}\text { Help seeking } \\
(5,6,9,10,12-14,26,27)\end{array}$ & $0.62-0.79$ & 0.95 & $2.04(0.689)$ & -1.38 \\
\hline $\begin{array}{l}\text { Symptom effects } \\
(24,25,33-35)\end{array}$ & $0.66-0.89$ & 0.92 & $2.01(0.641)$ & -0.88 \\
\hline $\begin{array}{l}\text { Treatment experience } \\
(11,15,29-31)\end{array}$ & $0.56-0.7$ & 0.85 & $2.02(0.637)$ & -0.99 \\
\hline
\end{tabular}

Table 2 The final model factors' loadings, item-total correlations, Cronbach's $\alpha$ if items deleted

\section{Questions}

Factor

loadings

Corrected item- Cronbach's $\alpha$ if total correlation item deleted

\section{Fear}

Q1: Do you worry about your health?

$\begin{array}{lll}0.72 & 0.67 & 0.96 \\ 0.89 & 0.87 & 0.95 \\ 0.66 & 0.62 & 0.96 \\ 0.91 & 0.89 & 0.95 \\ 0.82 & 0.78 & 0.95 \\ 0.83 & 0.79 & 0.95 \\ 0.83 & 0.80 & 0.95 \\ 0.76 & 0.73 & 0.95 \\ 0.88 & 0.85 & 0.95 \\ 0.74 & 0.71 & 0.96 \\ 0.83 & 0.79 & 0.95 \\ 0.77 & 0.73 & 0.95 \\ 0.90 & 0.87 & 0.95\end{array}$

Q2: Are you worried that you might get really sick in the future?

Q3: Does the thought of being sick scare you?

Q4: If you have pain, do you worry that it may be caused by a bad sickness?

Q7: If pain lasts for a week or more, do you believe that you have a bad sickness?

Q16: If a doctor tells you what he/she found, do you soon begin to believe that you might have another sickness?

Q17: Are you afraid of news that reminds you of death?

Q18: Does the thought of dying scare you?

Q19: Are you afraid that you might die soon?

Q20: Are you afraid that you might have cancer?

Q21: Are you afraid that you have something wrong with your heart?

0.87

0.95

Q23: When you read or hear about a sickness, do you think that you might have that sickness?

Q5: If pain lasts for a week or more, do you tell your mom or dad?

Q6: If pain lasts for a week or more, do you ask your mom or dad if you can go to the doctor?

Q9: Do you try not to eat foods that may not be good for you (such as junk food)?

Q10: Do you check your body to find out if there is something wrong?

Q26: When you have a strange feeling in your body, do you tell your mom or dad?

\section{Symptoms effects}

Q24: When you have a strange feeling in your body, do you find it hard to think about something else?

Q25: When you have a strange feeling in your body, do you worry about it?

Q35: Do strange feelings in your body stop you from keeping your mind on what you are doing?

\section{Treatment experience}

Q11: Do you believe that you are really sick, but the doctors do not know why?

$0.84 \quad 0.71$

Q15: When your doctor tells you that you are not sick, do you not believe him/her? 
asks about habits rather than previous experience with doctors, unlike the remaining items in this factor. Cultural differences may lie behind these differences found between our study and Wright et al., in addition to design differences including a substantially larger sample size. Furthermore, we performed cognitive interviews to ensure that the questions were clear for children. We believe that the questions were clear because we found high internal consistency and test-retest reliability.

Future work may include confirming diagnostic credibility of the Arabic version of the CIAS by evaluating the scores of children with confirmed diagnoses of health anxiety or hypochondriasis and comparing them to a control group. This could address a limitation found in this study, which is not evaluating the scores of the Arabic version of the CIAS for different health conditions.

Different studies with adults have confirmed that there are correlations between different medical conditions and health anxiety including, for example, chronic pain (28) and cardiovascular disease (29). Therefore, the Arabic version of CIAS can be used to measure health anxiety in different diseases.

Evaluating health anxiety could also be important when treating different health conditions. For example, it has been shown that patients with high health anxiety react differently to pain when compared to patients with low health anxiety (30). This is manifested in differences in pain appraisal, pain preoccupation, coping strategies, self-identity, and suicidal ideation. In addition, patients with health anxiety may fail to engage in protective strategies (31), which may have an impact on the success of management of their condition. Therefore, using the
Arabic version of CIAS could help in the management of different diseases and future work may include measuring the benefit of detection and management of health anxiety when managing different conditions. As this tool can be used for screening different patients, particularly those who are reporting contradicting symptoms, this could save healthcare costs.

Finally, the Arabic version of the CIAS can be used to compare the prevalence of health-related anxiety in Arabic-speaking countries, which has hitherto not been possible. It will also now be possible to make comparisons between health-related anxiety with data collected using the English language version of the scale.

A limitation of this study was that the children enrolled were only from schools from Amman. However, Amman is the largest city in Jordan; almost half of the Jordanian population lives there (4 million inhabitants) (32), and many come from different parts of the country for work, which makes Amman a good representation of Jordan.

\section{Conclusion}

This validated Arabic version of the CIAS questionnaire (15) could be used to evaluate health anxiety in children by examining the overall scores and the scores of the different subscales, which could aid in diagnosis and management of health anxiety in children across the Arabic-speaking world.

Funding: None.

Competing interests: None declared.

\section{Validation de la version arabe de l'échelle d'attitude à l'égard de la maladie chez l'enfant}

\section{Résumé}

Contexte : Une anxiété excessive en matière de santé peut entraîner des troubles importants tels que l'hypocondrie. Chez l'enfant, l'évaluation de la gravité de l'anxiété liée à la santé a été réalisée à l'aide de l'échelle d'attitude à l'égard de la maladie chez l'enfant; cependant, aucune version arabe validée de cet outil n'existe.

Objectifs : La présente étude a mis au point et a validé une version arabe du questionnaire des échelles d'attitude à l'égard de la maladie chez l'enfant en Jordanie en 2017 afin de fournir un outil permettant de mesurer la gravité de l'anxiété liée à la santé dans le monde arabophone.

Méthodes : Le questionnaire susmentionné a été traduit de l'anglais vers l'arabe. il a ensuite fait l'objet d'une rétro-traduction par un autre traducteur et les deux versions ont été comparées avant la réalisation des entretiens cognitifs. La version finale du questionnaire a été distribuée à 597 enfants. Parmi ceux-ci, 200 ont été invités à répondre de nouveau au questionnaire après 10 à 15 jours pour évaluer la fiabilité test-retest. Une analyse factorielle confirmatoire sur le modèle à quatre facteurs basé sur la version originale du questionnaire a été réalisée. La cohérence interne et la fidélité test-retest ont été évaluées.

Résultats : L'analyse factorielle confirmatoire a montré un bon ajustement (indice d'ajustement $=0,92$ ) avec le modèle à quatre facteurs des peurs, de la recherche d'aide, de l'expérience du traitement et des effets des symptômes. La fiabilité test-retest était élevée et le modèle avait une bonne validité discriminante et une bonne cohérence interne.

Conclusions : La version arabe de l'Échelle d'attitude à l'égard de la maladie chez l'enfant fournit un outil approprié pour enquêter sur la prévalence et la gravité de l'anxiété infantile au Moyen-Orient. 


\section{التحقق من موثوقية النسخة العربية لمقاييس التجاهات أمر اض الطفولة \\ وليد الكريم، جوناثان لينج، واسان جرار}

الخلاصة

الخلفية: يمكن أن يؤدي القلق الصحي المفرط إلى اضطر ابات كبيرة مثل التوهم المرضي. أجري، في الأطفال، تقييم لشدة القلق الصحي بمقاييس

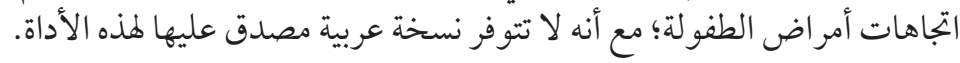

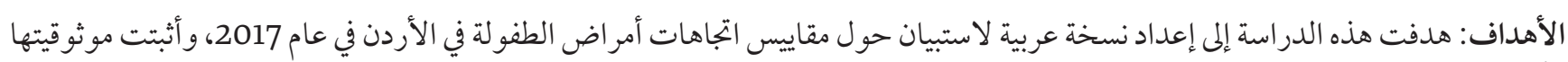

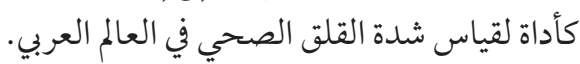

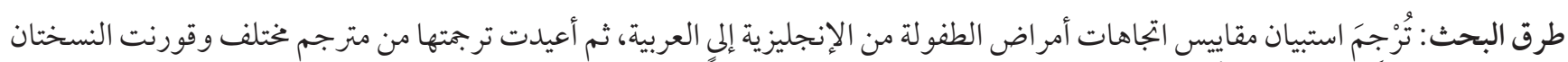

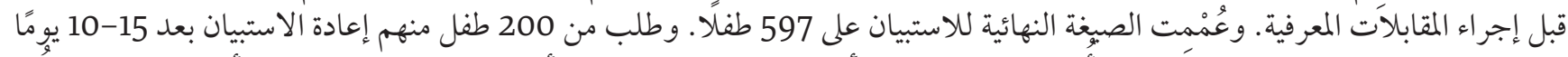

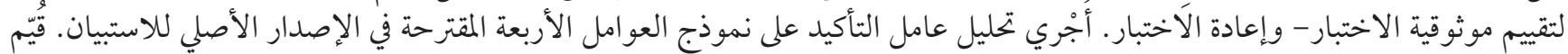
الاتساق الداخلي وموثوقية الاختبار - و وإعادة الآختبار.

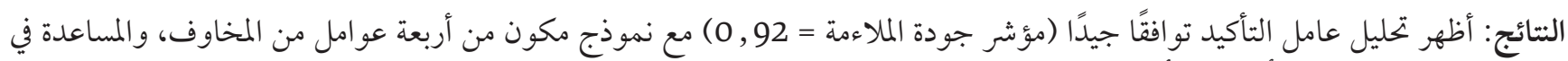

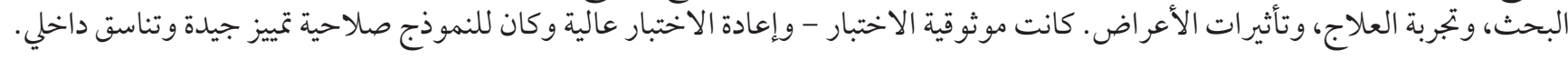

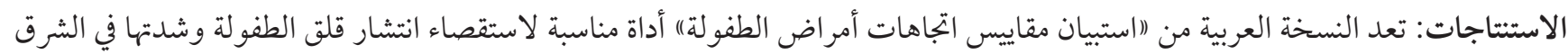

\section{References}

1. Asmundson GJG, Abramowitz JS, Richter AA, Whedon M. Health anxiety: current perspectives and future directions. Curr Psychiatry Rep. 2010 Aug;12(4):306-12. http://dx.doi.org/10.1007/s11920-010-0123-9 PMID:20549396

2. Taylor S, Asmundson GJ. Etiology of hypochondriasis: a preliminary behavioral-genetic investigation. Int J Genet Gene Ther. 2012;2:1-5. http://dx.doi.org/10.5348/ijggt-2011-1-SR-1

3. Barsky AJ, Klerman GL. Overview: hypochondriasis, bodily complaints, and somatic styles. Am J Psychiatry. 1983 Mar;140(3):27383. http://dx.doi.org/10.1176/ajp.140.3.273 PMID:6338747

4. Salkovskis PM, Warwick HMC. Morbid preoccupations, health anxiety and reassurance: a cognitive-behavioural approach to hypochondriasis. Behav Res Ther. 1986;24(5):597-602. Htrp://dx.doi.org/10.1016/0005-7967(86)90041-o PMID:3753387

5. Deacon BJ, Abramowitz JS. Is hypochondriasis related to obsessive-compulsive disorder, panic disorder, or both? An empirical evaluation. J Cogn Psychother. 2008;22(2):115-27. http://dx.doi.org/10.1891/0889-8391.22.2.115 PMID:3753387

6. Austin JK, Smith MS, Risinger MW, McNelis AM. Childhood epilepsy and asthma: comparison of quality of life. Epilepsia. 1994 May-Jun;35(3):608-15. PMID:8026407

7. Fritz GK, Fritsch S, Hagino O. Somatoform disorders in children and adolescents: a review of the past 10 years. J Am Acad Child Adolesc Psychiatry. 1997 Oct;36(10):1329-38. http://dx.doi.org/10.1097/00004583-199710000-00014 PMID:9334545

8. Puri PR, Dimsdale JE. Healthcare utilization and poor reassurance:potential predictors of somatoform disorders. Psychiatr Clin North Am. 2011 Sep;34(3):525-44. http://dx.doi.org/10.1016/j.psc.2011.05.011 PMID:21889677

9. Houtveen JH, van Broeckhuysen-Kloth S, Lintmeijer LL, Bühring MEF, Geenen R. Intensive multidisciplinary treatment of severe somatoform disorder. J Nerv Ment Dis. 2015 Feb;203(2):141-8. http://dx.doi.org/10.1097/NMD.0000000000000250 PMID:25594786

10. Ibeziako P, Bujoreanu S. Approach to psychosomatic illness in adolescents. Curr Opin Pediatr. 2011 Aug;23(4):384-9. http://dx.doi. org/10.1097/MOP.obo13e3283483fic PMID:21670681

11. Weck F, Bleichhardt G, Hiller W. The factor structure of the illness attitude scales in a German population. Int J Behav Med. 2009;16(2):164-71. http://dx.doi.org/10.1007/s12529-009-9043-7 PMID:19319692

12. Eminson M, Benjamin S, Shortall A, Woods T, Faragher B. Physical symptoms and illness attitudes in adolescents: an epidemiological study. J Child Psychol Psychiatry Allied Discip. 1996 Jul;37(5):519-28. http://dx.doi.org/10.1111/j.1469-7610.1996.tbo1438.x PMID:8807432

13. Muris P, Merckelbach H, Mayer B, Prins E. How serious are common childhood fears? Behav Res Ther. 2000 Mar;38(3):217-28. PMID:10665156

14. Muris P, Merckelbach H, Gadet BMV. Fears, worries, and scary dreams in 4- to 12-year-old children:their content, developmental pattern, and origins. J Clin Child Psychol. 200o Mar;29(1):43-52. http://dx.doi.org/10.1207/S15374424jccp2901_5 PMID:10693031

15. Wright KD, Asmundson GJG. Brief report: factor structure of the Childhood Illness Attitude Scales (CIAS). J Pediatr Psychol. 2005 Mar;30(2):213-8. http://dx.doi.org/10.1093/jpepsy/jsioog PMID:15681316 
16. Wright KD, Asmundson GJG. Health anxiety in children: development and psychometric properties of the Childhood Illness Attitude Scales. Cogn Behav Ther. 2003;32(4):194-202. http://dx.doi.org/10.1080/16506070310014691 PMID:16291551

17. Malas N, Ortiz-Aguayo R, Giles L, Ibeziako P. Pediatric somatic symptom disorders. Curr Psychiatry Rep. 2017 Feb;19(2):11. http:// dx.doi.org/10.1007/s11920-017-0760-3 PMID:28188588

18. Andresen JM, Woolfolk RL, Allen LA, Fragoso MA, Youngerman NL, Patrick-Miller TJ et al. Physical symptoms and psychosocial correlates of somatization in pediatric primary care. Clin Pediatr (Phila). 2011 Oct;50(10):904-9. http://dx.doi. org/10.1177/0009922811406717 PMID:21576182

19. Kellner R. Abridged manual of the illness attitude scales. University of New Mexico, Department of Psychiatry, School of Medicine; 1987.

20. Ollendick TH. Reliability and validity of the revised fear survey schedule for children (FSSC-R). Behav Res Ther. 1983;21(6):68592. https://doi.org/10.1016/0005-7967(83)90087-6

21. Silverman WK, Fleisig W, Rabian B, Peterson RA. Childhood Anxiety Sensitivity Index. J Clin Child Psychol. 1991;20(2):162-8. http://dx.doi.org/10.1207/s15374424jccp2002_7

22. Kovacs M. Children's depression inventory manual. Toronto: Multi Health Systems; 1992.

23. Myers ND, Ahn S, Jin Y. Sample size and power estimates for a confirmatory factor analytic model in exercise and sport:a monte carlo approach. Res Q Exerc Sport. 2011 Sep;82(3):412-23. http://dx.doi.org/10.1080/02701367.2011.10599773 PMID:21957699

24. George D, Paul Mallery W. SPSS for Windows step by step a simple guide and reference. 17.0 update. Allyn \& Bacon; 2010.

25. Simon Moss. Fit indices for structural equation modeling [website]. Sicotests; 2016 (http://www.sicotests.com/psyarticle.asp?id=277, accessed 7 January 2020).

26. O'Connor BP. SPSS and SAS programs for determining the number of components using parallel analysis and Velicer's MAP test. Behav Res Methods, Instruments, Comput. 2000 Aug;32(3):396-402. http://dx.doi.org/10.3758/BF03200807 PMID:11029811

27. McHorney CA, Tarlov AR. Individual-patient monitoring in clinical practice: are available health status surveys adequate? Qual Life Res. 1995 Aug;4(4):293-307. PMID:7550178

28. Rode S, Salkovskis P, Dowd H, Hanna M. Health anxiety levels in chronic pain clinic attenders. J Psychosom Res. 2006 Feb;60(2):155-61. http://dx.doi.org/10.1016/j.jpsychores.2005.07.005 PMID:16439268

29. Steca P, Monzani D, Greco A, Franzelli C, Magrin ME, Miglioretti M et al. Stability and change of lifestyle profiles in cardiovascular patients after their first acute coronary event. PLoS One. 2017 Aug 29;12(8):e0183905. http://dx.doi.org/10.1371/journal. pone.0183905 PMID:28850579

30. Tang NKY, Salkovskis PM, Hodges A, Soong E, Hanna MH, Hester J. Chronic pain syndrome associated with health anxiety: a qualitative thematic comparison between pain patients with high and low health anxiety. Br J Clin Psychol. 2009 Mar;48(Pt 1):1-20. http://dx.doi.org/10.1348/014466508X336167 PMID:18724887

31. Hadjistavropoulos HD, Craig KD, Hadjistavropoulos T. Cognitive and behavioral responses to illness information: the role of health anxiety. Behav Res Ther. 1998 Feb;36(2):149-64. http://dx.doi.org/10.1016/Soo05-7967(98)ooo14-X PMID:9613022

32. Jordan statistical yearbook. Amman: Department of Statistics; 2016. 


\section{Appendix 1: Original CIAS:}

\section{Childhood Illness Attitude Scales}

K. D. Wright \& G. J. G. Asmundson (2003)

Directions: Below are a number of questions. Read each question carefully and put an $\mathrm{X}$ on the line in front of the words that best answers the question. There are no right or wrong answers. Remember, find the words that best answers the question.

\section{Question}

1. Do you worry about your health?

\begin{tabular}{|c|c|c|}
\hline $\begin{array}{l}\text { None of } \\
\text { the time }\end{array}$ & __ Sometimes & $\begin{array}{c}\text { A lot of } \\
\text { the time }\end{array}$ \\
\hline $\begin{array}{l}\text { None of } \\
\text { the time }\end{array}$ & __ Sometimes & — A lot of \\
\hline $\begin{array}{l}\text { None of } \\
\text { the time }\end{array}$ & __ Sometimes & $\begin{array}{c}\text { A lot of } \\
\text { the time }\end{array}$ \\
\hline
\end{tabular}

4. If you have pain, do you worry that it may be caused by a bad sickness?

_ None of

Sometimes

A lot of

2. Are you worried that you might get really sick in the future? the time the time

5. If pain lasts for a week or more, do you tell your mom or dad?

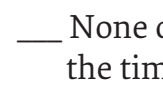

_ Sometimes__ A lot of

6. If pain lasts for a week or more, do you ask your mom or dad if you can go to the doctor?

_ None of the time

Sometimes

A lot of

7. If pain lasts for a week or more, do you believe that you have a bad sickness?

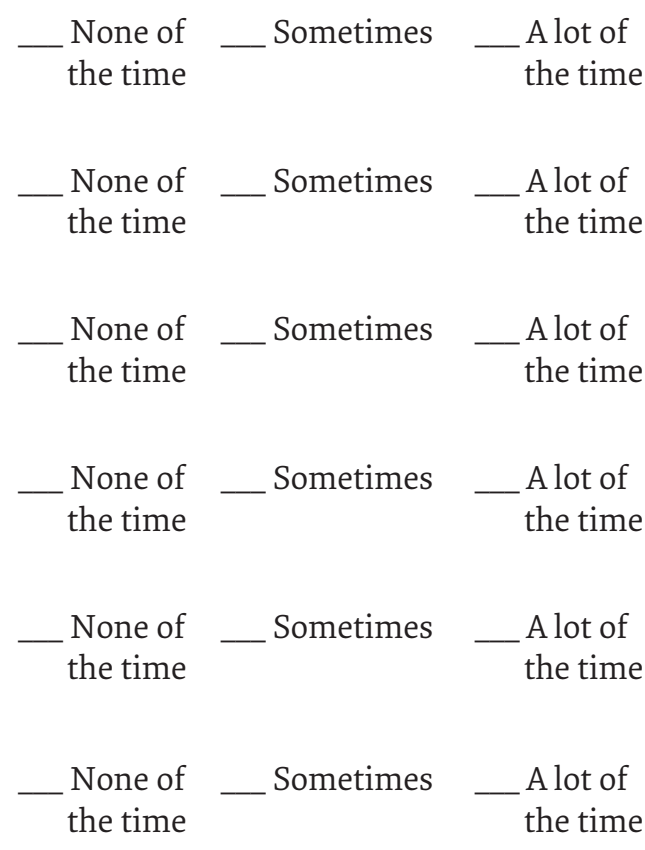

8. Do you try not to have habits that may be bad for you, such as smoking, drinking, or drugs?

9. Do you try not to eat foods that may not be good for you (such as junk food)?

10. Do you check your body to find out if there is something wrong?

11. Do you believe that you are really sick, but the doctors do not know why?

12. When you feel sick, do you tell your mom or dad?

$\begin{aligned} & \text { None of } \\ & \text { the time }\end{aligned}$
Sometimes
$\begin{aligned} & \text { None of } \\ & \text { the time }\end{aligned}$


15. When your doctor tells you that you are not sick, do you not believe him/her?

16. If a doctor tells you what he/she found, do you soon begin to believe that you might have another sickness?

17. Are you afraid of news that reminds you of death?

18. Does the thought of dying scare you?

19. Are you afraid that you might die soon?

20. Are you afraid that you might have cancer?

21. Are you afraid that you have something wrong with your heart?

22. Are you afraid that you have another bad sickness?

Which sickness?

23. When you read or hear about a sickness, do you think that you might have that sickness?

24. When you have a strange feeling in your body, do you find it hard to think about something else?

25. When you have a strange feeling in your body, do you worry about it?

26. When you have a strange feeling in your body, do you tell your mom or dad?

27. When you have a strange feeling in your body, do you ask your mom or dad if you can go to the doctor?

28. Has your doctor told you that you have a sickness?

If yes, what sickness?

29. How many times have you seen your doctor in the last year? _o times _ ${ }^{1-2}$ times $\quad 3$ or more

\begin{tabular}{|c|c|c|}
\hline $\begin{array}{l}\text { None of } \\
\text { the time }\end{array}$ & __ Sometimes & $\begin{array}{l}\text { A lot of } \\
\text { the time }\end{array}$ \\
\hline $\begin{array}{l}\text { None of } \\
\text { the time }\end{array}$ & __ Sometimes & $\begin{array}{l}\text { A lot of } \\
\text { the time }\end{array}$ \\
\hline $\begin{array}{l}\text { None of } \\
\text { the time }\end{array}$ & __ Sometimes & $\begin{array}{l}\text { A lot of } \\
\text { the time }\end{array}$ \\
\hline $\begin{array}{l}\text { None of } \\
\text { the time }\end{array}$ & __ Sometimes & $\begin{array}{l}\text { A lot of } \\
\text { the time }\end{array}$ \\
\hline $\begin{array}{l}\text { None of } \\
\text { the time }\end{array}$ & __ Sometimes & $\begin{array}{l}\text { A lot of } \\
\text { the time }\end{array}$ \\
\hline $\begin{array}{l}\text { None of } \\
\text { the time }\end{array}$ & __ Sometimes & $\begin{array}{l}\text { A lot of } \\
\text { the time }\end{array}$ \\
\hline $\begin{array}{l}\text { None of } \\
\text { the time }\end{array}$ & __ Sometimes & $\begin{array}{l}\text { A lot of } \\
\text { the time }\end{array}$ \\
\hline $\begin{array}{l}\text { None of } \\
\text { the time }\end{array}$ & __ Sometimes & $\begin{array}{l}\text { A lot of } \\
\text { the time }\end{array}$ \\
\hline
\end{tabular}

None of the time

None of
the time _ Sometimes__ A lot of

None of Sometimes__ A lot of the time the time
None of the time

Sometimes A lot of the time

None of the time

Sometimes___ A lot of the time

_ Yes _ No

- 0

1-2

_ 3 or more 
31. How often have you been treated (had to take medicine or had surgery) during the past year?

_o times _ ${ }^{1-2}$ times $\quad 3$ or more

32. If you have had treatments in the last year, what were they?

The next three questions concern feelings in your body (for example, pain, aches, pressure in your body, breathing problems, being tired etc.)

33. Do strange feelings in your body stop you from going to school?

34. Do strange feelings in your body stop you from enjoying yourself?

35. Do strange feelings in your body stop you from keeping your mind on what you are doing?

None of
the time Sometimes _ A lot of

None of _
the time Sometimes_ A lot of

_ None of _ Sometimes__ A lot of the time the time 


\section{Appendix 2: Translated CIAS}

\begin{tabular}{|c|c|c|c|}
\hline | الأوقثير من & أحيانا & إطلاقا & 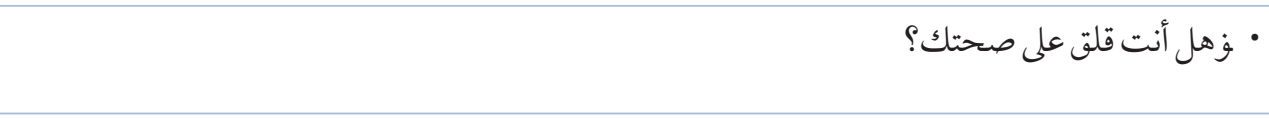 \\
\hline الأكثير من & أحيانا & إطلاقا & ح مريضا جدا في المستقبل؟ \\
\hline الأوقثير من & أحيانا & إطلاقا & • هل فكرة أن تكون مريض تخيفك؟ \\
\hline | الأكثير من & أحيانا & إطلاقا & • إذا شعرت بالألم هل تقلق من أن يكون سبب الألم مرض سيء؟ \\
\hline الأوقير من & أحيانا & إطلاقا & • إذا استمر الألم لأسبوع أو أكثرأهل تخبر والدتك أو والدك؟ \\
\hline الأوقير من & أحيانا & إطلاقا & • إذا استمر الألم لأسبوع أو أكثرأهل تطلب من والدتك أو والدك أن يأخذك الى الطبيب؟ \\
\hline الأوقير من & أحيانا & إطلاقا & • إذا استمر الألم لأسبوع أو أكثرأهل تعتقد أن لديك مرض سي؟؟ \\
\hline | الأوقير من & أحيانا & إطلاقا & • هل تحاول أن تقلع عن العادات التي مككن أن تكون سيئة على صحتك مثل التدخين؟ \\
\hline الأوقير من & أحيانا & إطلاقا & • هل تحاول أن تبتعد عن أكل الأغذية التي قد تكون مضرة بصحتك مثل البيتزاو الهامبرجر و الشاورما؟ \\
\hline الأوقير من & أحيانا & إطلاقا & • هل تتفحص جسدك لترى إن كان هناك شيء غير طبيعي؟ \\
\hline الأوقير من & أحيانا & إطلاقا & • هل تعتقد أنك مريض جدا لكن الأطباء لا يعرفون سبب مرضك؟ \\
\hline | الأوقثير من & أحيانا & إطلاقا & • عندما تشعر أنك مريضلهل تخبر والدتك أو والدك؟ \\
\hline | الأوقير من & أحيانا & إطلاقا & •عندما تشعر أنك مريض|ّل تطلب من والدتك أو والدك أن يأخذاك إلى الطبي؟؟ \\
\hline الأوقير من & أحيانا & إطلاقا & • هل تطلب من والدتك أو والدتك أن يخضر الك الدواء؟ \\
\hline الأوقير من & أحيانا & إطلاقا & •عندما يخبرك الطبيب أنك لست مريضاً هل تصدقه؟ \\
\hline الأوقير من & أحيانا & إطلاقا & • إذا أخبرك الطبيب تشخيصه هل تبدأ بالإعتقاد أن لديك مرض اخر؟ \\
\hline | الأكثير من & أحيانا & إطلاقا & • مل تخاف من الأخبار التي تذكرك بالموت؟ \\
\hline | الأكثير من & أحيانا & إطلاقا & 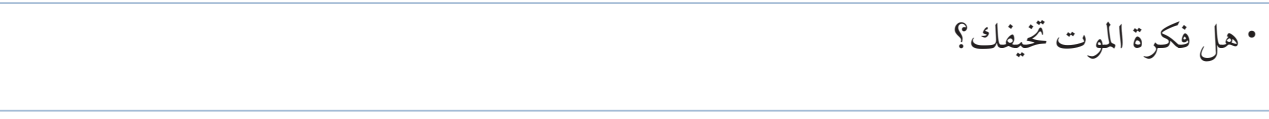 \\
\hline الأوقير من & أحيانا & إطلاقا & 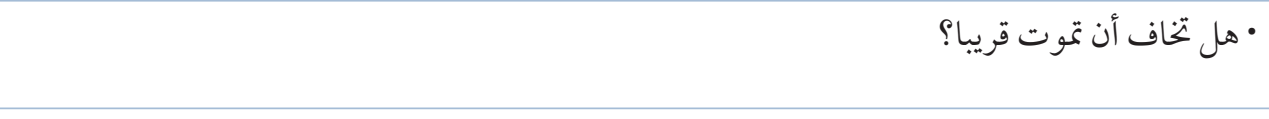 \\
\hline الأوقير من & أحيانا & إطلاقا & • هل تخاف أن تكون مصابا بالسرطان؟ \\
\hline الأوقير من & أحيانا & إطلاقا & • هل تخاف أن تكون مصابا بمرض في القلب؟ \\
\hline | - الأوقات من & أحيانا & إطلاقا & 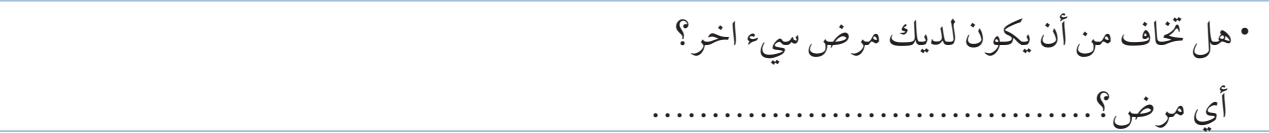 \\
\hline
\end{tabular}




\begin{tabular}{|c|c|c|c|}
\hline الأوقثير من & 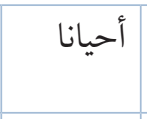 & |إطلاقا & •عندما تقرأ أو تسمع بمرض مأ هل تشعر أنه قد يكون لديك هذا المرض؟ \\
\hline الأوقات من & أحيانا & إطلاقا & • إذا شعرت أن لديك إحساس غريب في جسدكّ"هل يصعب عليك التفكير في شيء اخر؟ \\
\hline الأوقير من & أحيانا & إطلاقا & • إذا شعرت بإحساس غريب في جسدكَّ هل تقلق بشأنه؟ \\
\hline الأوقات من & 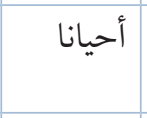 & إطلاقا & • • إذا شعرت بإحساس غريب في جسدكَّ هل تخبر و الدتك أو و الدك؟ \\
\hline \multirow{2}{*}{ الأوقات من } & 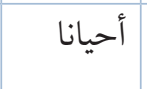 & | إطلاق & • إذا شعرت بإحساس غريب في جسدكَّ هل تطلب من والدتك أو والدك أن يأخذاك إلى الطبي؟؟ \\
\hline & نعم & ע & 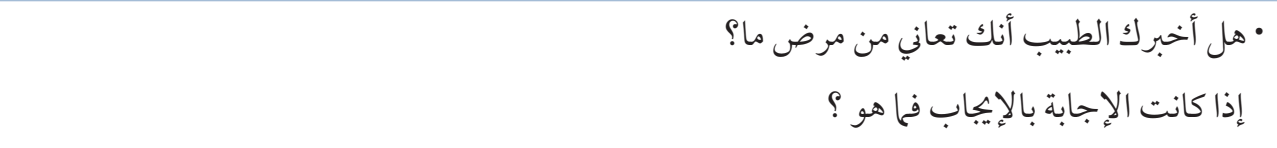 \\
\hline 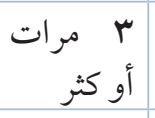 & r-1 مرة & نهائيا & • كم مرة زرت الطبيب خلال العام الماضي؟ \\
\hline 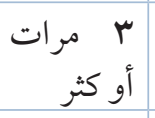 & 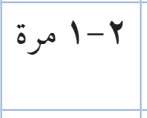 & نهائيا & 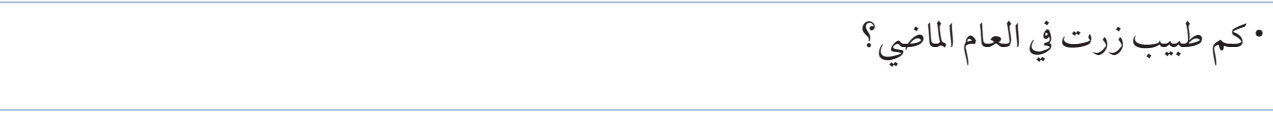 \\
\hline \multirow[t]{3}{*}{ أو كثر مرات } & 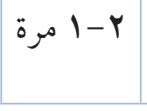 & نهائيا & • كم مرة تم علاجك ( خضعت لعملية أو أخذت دواء) خلال العام الماضي؟ \\
\hline & & & • إذا أخذت أي علاجات خلال العام الماضياّماذا كانت؟ \\
\hline & & & الأسئلة الثلاثة القادمة تتعلق بإحساس في جسدك (مثل الألما الأوجاع| صعوبة في التنفسل الاحساس \\
\hline الأوقثات من & أحيانا & إطلاقا & • هل الإحساس الغريب في جسدك يمنعك من الذهاب الى المدرسة؟ \\
\hline الأوقات من & أحيانا & إطلاقا & •هل الإحساس الغريب في جسدك يمنعك من الاستمتاع بو قتك؟ \\
\hline الأوقثر من & 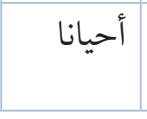 & إطلاقا & • هل الإحساس الغريب في جسدك يمنعك من التركيز فيما تقوم به؟ \\
\hline
\end{tabular}

